\title{
Measuring Alloxanthin as a Proxy Approach in a Study of Trophic Relationships between Zooplankton and Cryptophyte Algae in Lake Shira
}

\author{
Yuri V. Barkhatov*a, \\ Vladimir V. Zykova, Elena B. Khromechek ${ }^{\mathrm{a}}$, \\ Igor G. Prokopkin a and Denis Y. Rogozin ${ }^{\mathrm{a}, \mathrm{b}}$ \\ a Institute of Biophysics \\ FRC «Krasnoyarsk Science Center SB RAS» \\ Krasnoyarsk, Russian Federation \\ ${ }^{b}$ Siberian Federal University \\ Krasnoyarsk, Russian Federation
}

Received 01.10.2020, received in revised form 1.04.2021, accepted 15.05.2021

\begin{abstract}
Cryptophyte algae are an important trophic link in many aquatic ecosystems, but they remain insufficiently studied in terms of trophic interactions with other components of ecosystems. They are better quality food than most other algae and, therefore, can be subject to selective grazing by zooplankton; thus, direct measurements of the dynamics of their concentration in lakes may give very low productivity indicators. One way to assess the consumption of cryptophyte algae by zooplankton is to determine the content of alloxanthin, a carotenoid specific for cryptophyte algae, in zooplankton. The present study investigated the alloxanthin content of sedimentary silts, sedimentation traps, and zooplankton of Lake Shira using high performance liquid chromatography. A significant correlation was found between the abundance of some zooplankton species capable of consuming cryptophyte algae and the flux of precipitated alloxanthin recorded in sedimentation traps. Analysis of zooplankton samples (the largest contribution to the biomass of which was made by the copepod Arctodiaptomus salinus (Daday, 1885)) for the content of carotenoids during the spring-summer season showed the presence of alloxanthin amounts reaching $80 \mu \mathrm{g} / \mathrm{g}$, which decreased by the end of the season, and that correlated with the biomass of cryptophyte algae in the lake. Carotenoids associated with other groups of algae were observed in considerably smaller amounts. Thus, the copepod A. salinus exhibits high selective consumption of cryptophyte algae, which may serve as a confirmation of a close trophic relationship between them.
\end{abstract}

(C) Siberian Federal University. All rights reserved

This work is licensed under a Creative Commons Attribution-NonCommercial 4.0 International License (CC BY-NC 4.0).

* Corresponding author E-mail address: barkh@ibp.ru ORCID: 0000-0003-4547-0439 (Barkhatov Yu.); 0000-0002-9350-2936 (Rogozin D.); 0000-0002-3382-9339 (Zykov V.); 0000-0002-4546-885X (Prokopkin I.) 
Keywords: Cryptophyte algae, zooplankton, alloxanthin.

Acknowledgements. The authors are grateful to F. F. Kozlov, A. V. Drobotov, A.P. Tolomeev and E. S. Zadereev for their assistance during field studies.

The present study was funded by RFBR and Krasnoyarsk Krai Government and the Krasnoyarsk Regional Fund of Science, Project Number 19-44-240002.

Citation: Barkhatov Y.V., Zykov V.V., Khromechek E. B., Prokopkin I. G., Rogozin D. Y. Measuring alloxanthin as a proxy approach in a study of trophic relationships between zooplankton and cryptophyte algae in Lake Shira. J. Sib. Fed. Univ. Biol., 2021, 14(2), 154-167. DOI: 10.17516/1997-1389-0345

\title{
Каротиноид аллоксантин как индикатор \\ трофической связи зоопланктона \\ с криптофитовыми водорослями в озере Шира
}

\author{
Ю.В. Бархатова, В. В. Зыкова, \\ Е. Б. Хромечека, И. Г. Прокопкин, Д. Ю. Рогозин \\ ${ }^{a}$ Институт биофизики \\ ФИЦ «Красноярский научный изентр СО РАН» \\ Российская Федерачия, Красноярск \\ ${ }^{\sigma}$ Сибирский федеральный университет \\ Российская Федераџия, Красноярск
}

\begin{abstract}
Аннотация. Криптофитовые водоросли признаны важным трофическим звеном многих водных экосистем, однако остаются недостаточно изученными в плане трофических взаимодействий с другими компонентами экосистем. Они являются более качественной пищей, чем большинство других водорослей, и поэтому могут быть подвержены селективному выеданию со стороны зоопланктона. Следовательно, прямые измерения динамики их концентрации в озерах могут давать очень сильно заниженные показатели продукции. Одним из способов оценки потребления криптофитовых водорослей зоопланктоном служит определение содержания в нем специфического для криптомонад каротиноида аллоксантина. В работе исследовалось содержание аллоксантина в осадочных илах, седиментационных ловушках и зоопланктоне озера Шира с помощью высокоэффективной жидкостной хроматографии. Была показана значимая корреляция между количеством некоторых видов зоопланктона, способных потреблять криптофитовые водоросли, и потоком осаждаемого аллоксантина, зафиксированным в седиментационных ловушках. Результат анализа проб зоопланктона (наибольший вклад в биомассу которого обеспечивал веслоногий рачок Arctodiaptomus salinus (Daday, 1885)) на содержание каротиноидов в течение весенне-летнего сезона показал наличие аллоксантина в количестве до 80 мкг/г, снижающееся к концу сезона, что коррелировало с биомассой криптофитовых водорослей в озере. Каротиноиды, ассоциированные с другими группами водорослей, наблюдались в значительно меньшем


количестве. Это демонстрирует высокий уровень селективного потребления веслоногим рачком A.salinus криптофитовых водорослей и может служить подтверждением тесной трофической связи между ними.

Ключевые слова: криптофитовые водоросли, зоопланктон, аллоксантин.

Благодарности. Авторы благодарят сотрудников Института биофизики СО РАН Ф. Ф. Козлова, А.В. Дроботова, А.П. Толомеева, Е. С. Задереева за помощь в полевых работах.

Исследование выполнено при финансовой поддержке РФФИ и Правительства Красноярского края, Красноярского краевого фонда поддержки научной и научно-технической деятельности в рамках научного проекта № 19-44-240002.

Цитирование: Бархатов, Ю.В. Каротиноид аллоксантин как индикатор трофической связи зоопланктона с криптофитовыми водорослями в озере Шира / Ю. В. Бархатов, В. В. Зыков, Е.Б. Хромечек, И. Г. Прокопкин, Д. Ю. Рогозин // Журн. Сиб. федер. ун-та. Биология, 2021. 14(2). C. 154-167. DOI: 10.17516/1997-1389-0345

\section{Введение}

Характерной чертой многих стратифицированных водоемов является наличие многочисленной популяции криптофитовых водорослей или криптомонад (Cryptophyceae), адаптированной к низкому уровню освещенности в области хемоклина (Reynolds, 1992; Gervais, 1998). Представители семейства Cryptophyceae относятся к числу самых продуктивных жгутиконосцев в большинстве водных сред (Klaveness, 1988). Несмотря на небольшое видовое разнообразие (около 200 видов), криптофитовые водоросли характеризуются достаточно широкой экологической амплитудой, обитая как в пресных, так и в соленых водоемах (Науменко, 2014). Будучи источником незаменимых полиненасыщенных жирных кислот (Sushchik, 2008) и важным трофическим звеном многих солоноводных и пресноводных экосистем, они, тем не менее, остаются недостаточно изученными в плане трофических взаимодействий с другими компонентами экосистем.

Представляя собой одного из основных потребителей бактериальной биомассы хемоклина (Porter, 1988; Marshall, Laybourn-Parry, 2002), криптомонады сами служат источни- ком пищи для множества других организмов, в основном неспособных к длительному существованию в условиях отсутствия кислорода. Это инфузории, коловратки, кладоцеры и копеподы (Knisely, Geller, 1986). В зоне хемоклина пресс зоопланктона на криптофитовые водоросли значительно уменьшается, поскольку их важнейшие потребители не способны мигрировать в слои с низким уровнем кислорода, однако в озерах, где практически вся популяция криптомонад находится вне сульфидной зоны, она, очевидно, подвергается активному выеданию. Также известно, что криптомонады являются более качественной пищей, чем большинство других водорослей (Sushchik, 2008), и могут быть подвержены селективному выеданию со стороны зоопланктона (Eilertsen et al., 1989; Gladyshev et al., 1999; Tonno et al., 2016), поэтому прямые измерения динамики их концентрации в озерах могут давать очень сильно заниженные показатели продукции. Отмечается высокое содержание питательных веществ в культурах криптофитовых водорослей. Они содержат до 64 \% сухой массы белка с аспартатом, аланином, глутаматом, глицином, серином, лей- 
цином и лизином в качестве основных аминокислот (Dunstan et al., 2005).

Активные потребители криптофитовых водорослей среди прочих - веслоногие ракообразные (копеподы) (Talling, 2003; Tonno et al., 2016). Потребление такой питательной пищи ведет к более быстрому росту и ускоряет размножение копепод. Веслоногие ракообразные могут быть избирательными в потребляемой ими пище (Head, Harris, 1994; Meyer-Harms et al., 1999), и поэтому состав сообщества фитопланктона не обязательно отражается в содержании их кишечника. Эта особенность используется в определении спектра питания зоопланктона путем анализа содержания характерных для различных групп фитопланктона пигментов в кишечниках веслоногих рачков (McLeroyEtheridge, McManus, 1999; Antajan, Gasparini, 2004; Oechsler-Christensen et al., 2012; Tonno et al., 2016; D'Souza, Gauns, 2018). Также веслоногие рачки способны накапливать эти пигменты (каротиноиды) в тканях своего организма, что связывают в основном со способом защиты копепод от ультрафиолетовой радиации (Hairston, 1976; Sommaruga, 2010).

Одним из озер, в котором присутствует значительная популяция Cryptophyceae (Rhodomonas salina (Wislouch, 1924), ранее Cryptomonas salina), а доминирующим видом зоопланктона является веслоногий рачок Arctodiaptomus salinus (Daday, 1885), считают озеро Шира (Республика Хакасия) (N5430' E90 ${ }^{\circ} 11^{\prime}$ ) (Rogozin et al., 2017). Шира представляет собой меромиктическое соленое озеро с площадью поверхности 35,9 км² и максимальной глубиной 24 м (Degermendzhy et al., 2010). Концентрация растворенной соли в миксолимнионе колеблется с глубиной от 11,5 до 14,5 г/л, снижаясь до 9,5 г/л вблизи поверхности после таяния льда в мае. Трофический статус озера Шира оценивается как мезотрофный. Хемоклин в летние месяцы обычно располагается на глубине 13-16 м (Rogozin et al., 2009). В 2015-2016 годах произошло временное разрушение меромиксии озера, сопровождающееся значительными изменениями биомассы всех компонентов его экосистемы, в том числе криптофитовых водорослей, увеличивших свою численность в сотни раз (Rogozin et al., 2017).

Каротиноид аллоксантин хорошо известный таксономический маркер Cryptophyceae в природных водоемах (Leavitt, 1993; Antajan, Gasparini, 2004). Лютеин - характерный пигмент зеленых водорослей и высшей водной растительности, зеаксантин часто встречается у цианобактерий (Leavitt, 1993). Оба этих пигмента присутствуют в донных отложениях озера Шира, как и аллоксантин (Rogozin et al., 2011), и имеют схожую временную динамику. И зеленые водоросли, и цианобактерии постоянно присутствуют в фитопланктоне озера (Gaevsky et al., 2002).

В данной работе мы в первую очередь исследовали корелляционные связи потока осаждающегося на дно аллоксантина и биомассы различных компонентов экосистемы пелагиали озера Шира за период 2012-2017 годов. Конечной целью работы было определение трофической связи зоопланктона озера и криптофитовых водорослей и проверка гипотезы о возможности их селективного выедания. Для этого мы определяли содержание аллоксантина путем хроматографического анализа непосредственно в составе тканей зоопланктона озера Шира в течение весеннелетнего сезона 2020 года одновременно с мониторингом всех групп зоопланктона и криптофитовых водорослей в пелагиали озера.

\section{Материалы и методы}

Из центральной зоны озера Шира (N54³0'23.2" E90¹1'17.8') зоопланктон отбирали в течение весенне-летнего сезона 
с помощью зоопланктонной сети Джеди (82 мкм). Отбор проводили 15.05.2020, 26.06.2020 и 20.08.2020 с глубины 1-5 м. Отфильтрованный зоопланктон (большую часть которого по массе составляли рачки A. salinus) частично сразу замораживали, а частично экспонировали в течение суток в небольшом количестве озерной воды, взятой с того же горизонта в то же время, что исключало для зоопланктона возможность полноценного питания, но давало возможность опорожнения кишечника, после чего тоже замораживали. Замороженные пробы впоследствии использовали для хроматографического анализа на каротиноид аллоксантин, а также на каротиноиды лютеин и зеаксантин, которые считаются трофическими маркерами зеленых водорослей и цианобактерий соответственно. Пигментный анализ проводился по адаптированной методике (Wright et al., 1991) аналогично (Zykov et al., 2012). Образец рачков весом 2-4 г перемещали в отдельную пробиркуфалькон объемом 15 мл и заливали 10 мл 90 \%-го водного раствора ацетона. Экстракцию пигментов проводили при температуре минус $20{ }^{\circ} \mathrm{C}$ в течение суток. Затем экстракты центрифугировали при 6000 g в течение 10 мин, супернатант извлекали и до анализа хранили в темном месте при температуре минус $20^{\circ} \mathrm{C}$. HPLC-анализ производили на установке Agilent 1200 с DAD-детектором, хроматографическое разделение осуществляли по модифицированной методике Wright et al. (1991) на колонке Eclipse XDB-C18 (ср. диаметр частиц 5 микрон), линейные размеры 4,6 на 150 мм, также использовали предколонку Eclipse XDB-C18 с линейными размерами 4,6 на 12,5 мм. Разделение производили при температуре $400{ }^{\circ} \mathrm{C}$. Длина детектора 455 нм с шириной оптической щели 4 нм, референсный сигнал - 880 нм, ширина оптической щели 20 нм. Концентрацию каротиноидов в пробе рассчитывали по площади пика хроматограммы с калибровкой на основе стандарта каротиноидов по методике, изложенной в (Zykov et al., 2012).

Поскольку для задачи хроматографического анализа необходимо было получать и использовать как можно большую биомассу, это делало невозможным дифференциацию видов зоопланктона в пробах, однако параллельно в те же числа (15.05.2020, 26.06.2020 и 20.08.2020) производили мониторинг вертикального распределения всех групп зоопланктона и была рассчитана биомасса копепод и коловраток в столбе воды.

Пробы зоопланктона и криптофитовых водорослей отбирали в центральной части озера шланговым пробоотборником с разных глубин с интервалом 1 м от поверхности до нижней границы кислородного слоя. Пробы непосредственно после отбора фиксировали раствором Кузьмина (10 г йодида калия, 50 мл водяного дистиллята, 5 г йода, 5 мл хромовой кислоты (1 \%), 10 мл уксусной кислоты, 80 мл формалина (40 \%) (1\%) конечная концентрация) (Кузьмин, 1975). Перед подсчетом образцы концентрировали методом отстаивания (Hasle, 1978) от 1000 мл до примерно 50 мл. Криптофитовые водоросли подсчитывали в камере Фукса-Розенталя под световым микроскопом с использованием 10 псевдоповторностей. Определение биомассы криптофитовых водорослей осуществлялось методом клеточного объема согласно (Радченко и др., 2010). Концентрацию зоопланктона определяли подсчетом в камере Богорова с использованием всего объема пробы. Расчет биомассы зоопланктона осуществлялся согласно уравнению зависимости массы тела зоопланктера от его длины (Тевяшова, 2009) по среднему размеру организма в популяции озера Шира.

Седиментационные ловушки представляли собой открытые с верхнего конца по- 
липропиленовые цилиндры длиной 580 мм, диаметром 103 мм с прозрачным днищем из плексигласа. Ловушки экспонировались на глубине 20 м в анаэробной зоне, в центральной глубоководной части озера. При постановке точное местонахождение каждой ловушки фиксировали с помощью GPS (N 54.30.350, E 90.11.350) (Rogozin et al., 2017). На одном горизонте устанавливали две ловушки, данные по которым усредняли. Ловушки размещали на одном капроновом шнуре, установленном на якоре, с буем на верхнем конце для придания шнуру вертикального положения. Буй располагался на глубине 2-3 м от поверхности воды для снижения воздействия волн, а также во избежание вмораживания в лед.
Ловушки экспонировались без сигнального буйка, а извлекались методом траления.

Точные даты постановки и выемки ловушек приведены в табл. 1. В марте ловушки устанавливали через отверстие во льду. Поскольку извлечь ловушку в марте из-подо льда было невозможно, мы поступали следующим образом: ловушка, установленная в октябре перед ледоставом, извлекалась в мае одновременно с ловушкой, установленной в марте. Разность содержимого ловушки «октябрьмай» и ловушки «весна» интерпретировалась как осадочный поток в период октябрь-март.

После извлечения из воды и транспортировки на берег ловушки выдерживали в вертикальном положении 4 ч, затем сливали

Таблица 1. Даты установки и выемки седиментационных ловушек в озере Шира за период 2012-2017 годов и рассчитанные потоки аллоксантина

Table 1. Dates of installation and removal of sedimentation traps in Lake Shira over the period of 2012-2017 and calculated fluxes of alloxanthin

\begin{tabular}{cccc}
\hline Дата постановки & $\begin{array}{c}\text { Дата } \\
\text { выемки }\end{array}$ & Время экспозиции, сут & $\begin{array}{c}\text { Поток на дно пигмента } \\
\text { аллоксантина, мг/(м².сут) }\end{array}$ \\
\hline 14.03 .2012 & 26.05 .2012 & 73 & 0,067 \\
27.05 .2012 & 07.07 .2012 & 41 & 0,157 \\
08.07 .2012 & 04.09 .2012 & 58 & 0,136 \\
04.09 .2012 & 24.10 .2012 & 50 & 0,144 \\
24.10 .2012 & 16.03 .2013 & 143 & 0,023 \\
16.03 .2013 & 31.05 .2013 & 76 & 0,073 \\
31.05 .2013 & 08.07 .2013 & 38 & 0,166 \\
10.07 .2013 & 03.09 .2013 & 55 & 0,197 \\
04.09 .2013 & 23.10 .2013 & 49 & 0,174 \\
24.10 .2013 & 13.03 .2014 & 140 & 0,049 \\
13.03 .2014 & 26.05 .2014 & 74 & 0,097 \\
28.05 .2014 & 09.07 .2014 & 42 & 0,274 \\
10.03 .2016 & 25.05 .2016 & 76 & 0,080 \\
25.05 .2016 & 03.08 .2016 & 70 & 0,339 \\
06.08 .2016 & 16.10 .2016 & 71 & 0,248 \\
16.10 .2016 & 11.03 .2017 & 146 & 0,050 \\
11.03 .2017 & 27.05 .2017 & 77 & 0,103 \\
27.05 .2017 & 04.08 .2017 & 69 & 0,162 \\
04.08 .2017 & 24.10 .2017 & 81 & 0,189 \\
\hline
\end{tabular}


верхнюю часть воды через сливные отверстия, расположенные на уровне 100 мм от дна. Остаток тщательно размешивали в оставшемся объеме воды, равном 900 мл, полученную суспензию переливали в пластиковые емкости, герметично закрывали без пузырька воздуха и хранили в герметичных пластиковых бутылках без воздуха в темноте при $4{ }^{\circ} \mathrm{C}$.

Для анализа каротиноидов (включая аллоксантин) определенный объем суспензии фильтровали через стекловолоконный фильтр GF/F и высушивали в темноте при комнатной температуре, а затем хранили фильтры при минус $20{ }^{\circ} \mathrm{C}$ в герметично запечатанных полиэтиленовых пакетах. Экстракцию каротиноидов из материала ловушек и их анализ с помощью высокоэффективной жидкостной хроматографии проводили, как описано Зыковым с соавторами (Zykov et al., 2012).

Седиментационный поток рассчитывали по формуле

$$
F=\frac{M}{S \Delta t}
$$

где $F$ - поток (г м ${ }^{-2}$ сут $\left.^{-1}\right) ; \mathrm{M}$ - масса аллоксантина в ловушке (г); $S$ - площадь захвата ловушки, равная $0,00832 \mathrm{~m}^{2} ; \Delta t-$ длительность экспозиции ловушки (сут).

Корреляционный анализ проводили между рассчитанным седиментационным потоком аллоксантина и численностью в столбе воды зоопланктона и криптофитовых водорослей, отобранных в даты конца периода экспонирования седиментационных ловушек.

\section{Результаты и обсуждение}

В 2012-2014 и 2016-2017 годах в озере экспонировались седиментационные ловушки, предназначенные для определения потока биогенных веществ, осаждаемых в придонную область в различные сезоны. В ловушках также определялись пигменты, в том числе таксономический маркер криптофитовых водорослей аллоксантин, и был рассчитан его суточный поток (табл. 1). В донных илах содержание аллоксантина оценивалось ранее (Zykov et al., 2012) и составляло порядка 100 мкг/г сухого вещества в верхних слоях. Однако динамика криптофитовых водорослей, непосредственно наблюдаемая в 2012-2020 годах в озере Шира, не показывает достоверной корреляции с содержанием аллоксантина как в донных отложениях, так и в осадочных ловушках. Такая корреляция найдена только между содержанием аллоксантина в осадочных ловушках и численностью некоторых видов зоопланктона - веслоногого рачка A. salinus и коловратки Hexarthra sp. (рис. 1). Для другой присутствующей в озере коловратки Brachionus plicatilis (Müller, 1786) достоверной корреляции с содержанием аллоксантина в осадочных ловушках не наблюдается. Коэффициент корреляции Пирсона составляет 0,63 для копеподы A. salinus и 0,65 для коловратки Hexarthra sp. и является достоверным для уровня 0,95. Таким образом, эти положительные достоверные корреляции косвенно могут свидетельствовать, что эти организмы служат потребителями источника аллоксантина в озере, то есть криптомонад R. salina, в значительных количествах.

Вертикальные распределения веслоногого рачка A. salinus и коловраток Hexarthra sp. и B. plicatilis (рис. 2) в 2020 году характерны для озера и близки к таковым в предыдущие годы наблюдений. Они более или менее равномерно распределены по всей кислородной зоне. Численность A. salinus достаточно стабильна весь сезон и составляет от 15 до 40 экз/л, число коловраток возрастает к концу лета и достигает 80 экз/л в основном за счет B. plicatilis. Согласно полученным вертикальным распределениям рассчитана биомасса копепод и коловраток в столбе воды (рис. 3). 


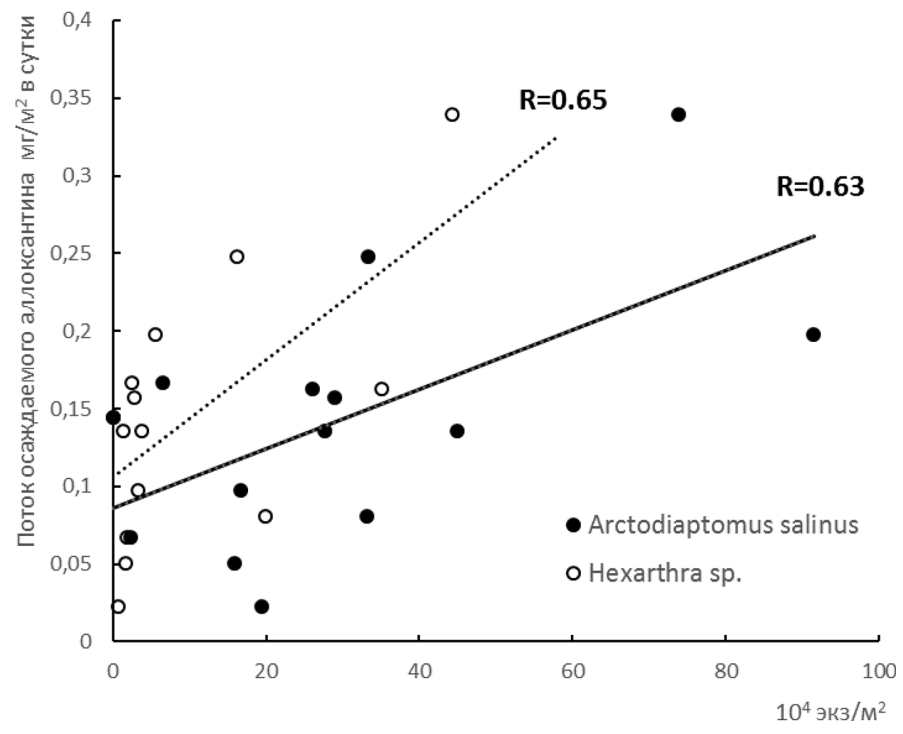

Рис. 1. Связь численности Arctodiaptomus salinus и Hexarthra sp. в озере Шира и потока осаждаемого аллоксантина за период 2012-2017 гг. R - коэффициент корреляции Пирсона

Fig. 1. Relationship between the abundance of Arctodiaptomus salinus and Hexarthra sp. in Lake Shira and the flux of precipitated alloxanthin for the period of 2012-2017. R is Pearson's correlation coefficient

Во все даты наибольший вклад в биомассу зоопланктона обеспечивал веслоногий рачок A. salinus.

Криптофитовые водоросли $R$. salina во все даты присутствуют практически во всех тех же горизонтах, что и их потенциальные потребители - копеподы и коловратки (рис. 2). Их вертикальное распределение показывает максимальную численность в начале сезона с заглубленным пиком и более ровное распределение в начале и конце лета (рис. 2) с достаточно сильным снижением биомассы в столбе воды к августу, от почти

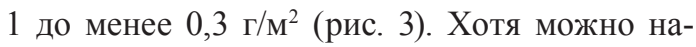
блюдать некоторое подобие отдельных пиков распределения криптофитовых водорослей с распределением зоопланктона, достоверной корреляции между этими распределениями не наблюдается.

Результаты определения пигментов в пробах зоопланктона представлены на рис. 4. Прежде всего, видно, что аллоксантина, связанного с криптофитовыми во- дорослями, в экстрактах зоопланктона в любой из проб либо значительно больше, либо столько же, по сравнению с пигментами зеленых водорослей и цианобактерий. Тогда как последних в озере Шира обычно как минимум на порядок больше по биомассе, чем криптофитовых водорослей (биомасса зеленых водорослей и цианобактерий в столбе воды - до 25 г/м² (Gaevsky et al., 2002), криптофитовых водорослей - менее 1 г/м² (см. рис. 3). Также мы наблюдаем снижение содержания аллоксантина в зоопланктоне в летний период относительно весеннего, что соответствует снижению общей биомассы криптофитовых водорослей в озере в этот период (рис. 3 и 4). Наконец, содержание аллоксантина в «голодных» рачках с опорожненными кишечниками выше, чем у рачков с кишечниками полными (рис. 4), что показывает активное накопление пигмента в теле рачка.

На рис. 3 и 4 видно, что относительное уменьшение биомассы криптомонад и увеличение массы зоопланктона соответствует 

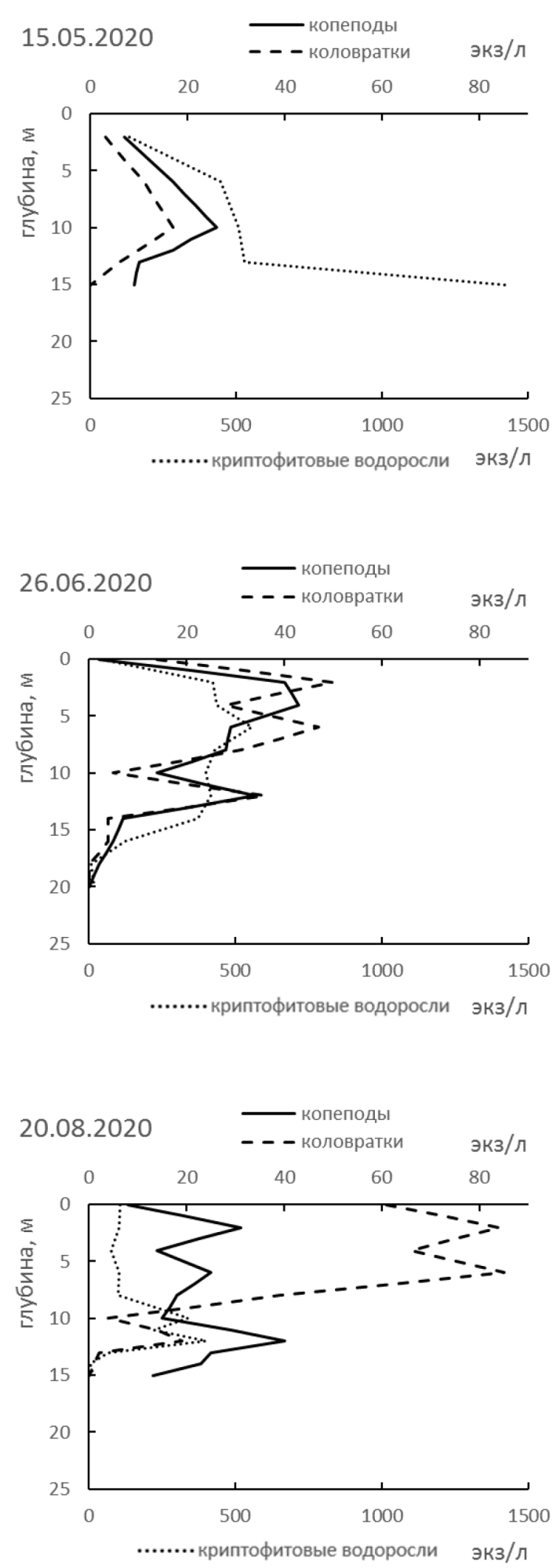

Рис. 2. Вертикальное распределение численности копепод и коловраток (верхняя ось) и криптофитовых водорослей (нижняя ось) в пелагиальной зоне озера Шира в 2020 году

Fig. 2. Vertical distribution of the abundance of copepods and rotifers (upper axis) and cryptophyte algae (lower axis) in the pelagic zone of Lake Shira in 2020 

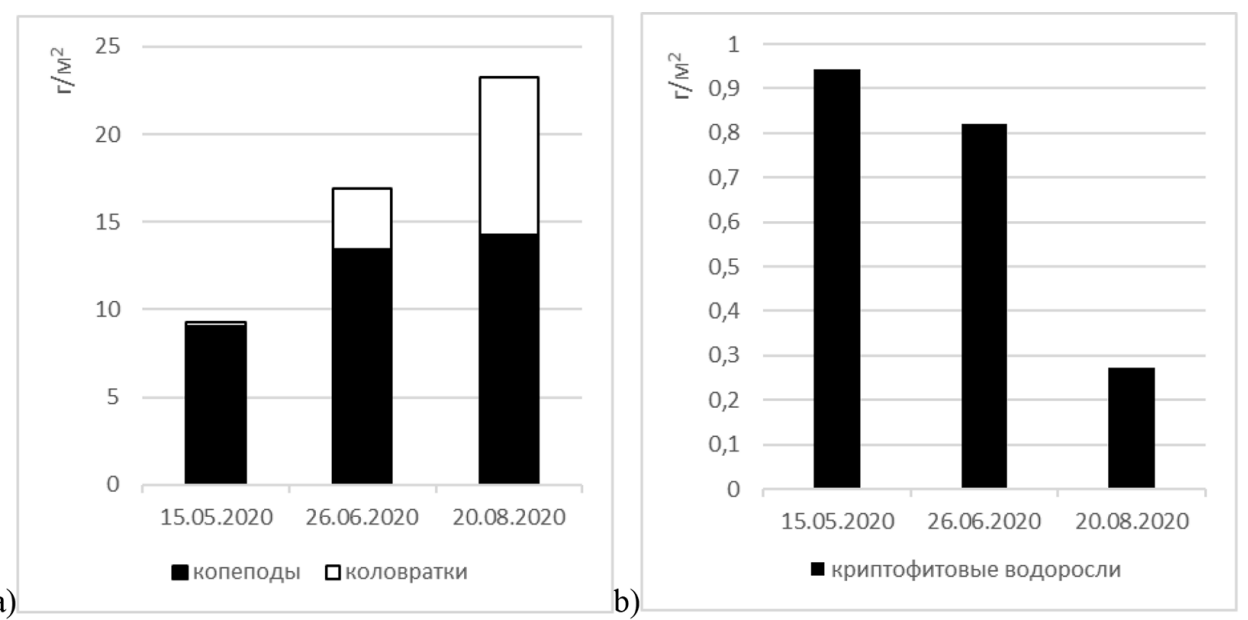

Рис. 3. Биомассса зоопланктона (а) и криптофитовых водорослей (b) в столбе воды озера Шира в весеннелетний сезон 2020 года

Fig. 3. Biomass of zooplankton (a) and cryptophyte algae (b) in the water column of Lake Shira in the springsummer season of 2020
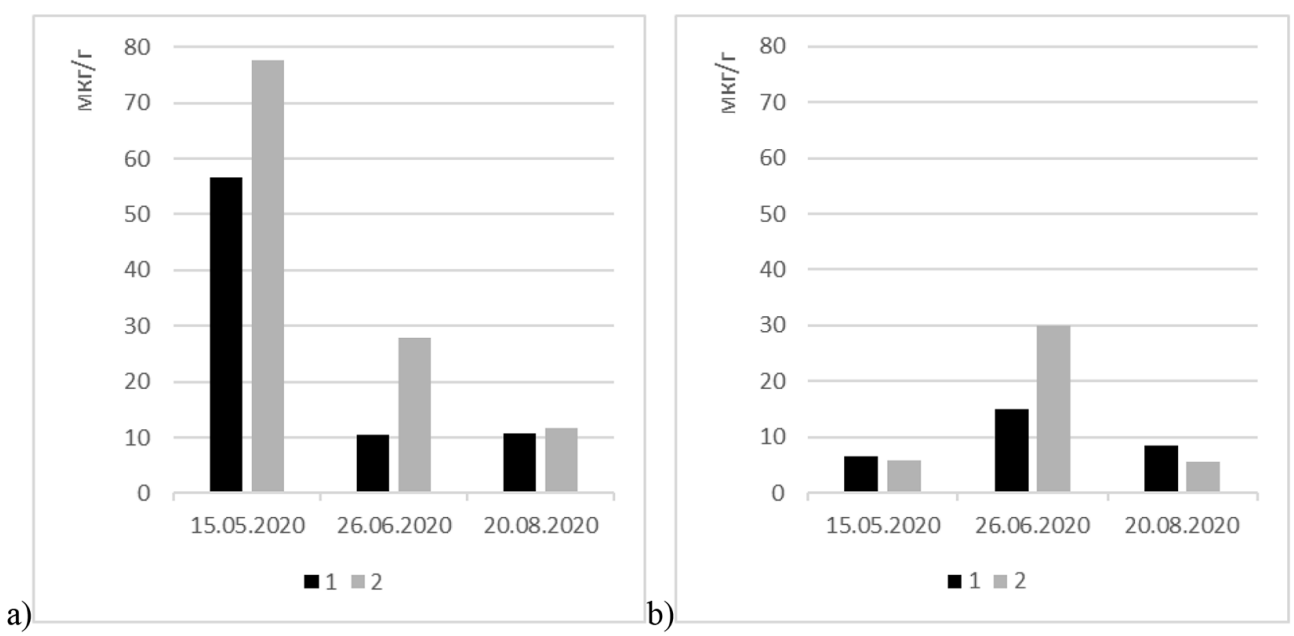

Рис. 4. Содержание каротиноидов аллоксантина (а) и лютеина и зеаксантина (b) в зоопланктоне из озера Шира сразу после отбора из природной среды (1) и после содержания в течение суток без доступа к пище (2)

Fig. 4. The content of carotenoids alloxanthin (a) and lutein and zeaxanthin (b) in zooplankton from Lake Shira immediately after sampling from the natural environment (1) and after keeping for 24 hours without access to food (2)

меньшему содержанию аллоксантина в тканях зоопланктона. Такая зависимость, среди других возможных гипотез, может объясняться селективным выеданием криптомонад зоопланктоном, поскольку при меньшем содержании криптомонад в среде веслоногие рачки уже не могут накапливать аллоксантин в достаточном для себя количестве. Отсутствие же корреляции между содержанием аллоксантина в осадочных илах и седиментационных ловушках и численностью криптофитовых водорослей может говорить о том, 
что практически весь вырабатываемый R. salina аллоксантин перехватывается зоопланктоном, то есть почти вся популяция криптофитовых водорослей в озере выедается, а в седиментационные ловушки и донные осадки попадает в составе тел мертвого зоопланктона.

Полученные нами данные в целом согласуются с результатами других исследований. Так, в озере Выртсъярв веслоногие ракообразные (в основном Cyclops kolensis) предпочтительно потребляли криптофиты (идентифицируемые по аллоксантину в содержимом кишечника) в более холодные периоды, а в более теплые предпочитали диатомовые и зеленые водоросли (определяемые по диатоксантину и лютеину соответственно) (Tonno et al., 2016). Descy et al. (1999) описали эксперимент с кормлением Diaptomus minutus водорослевым сообществом, состоящим из равной биомассы диатомовых, криптомонад и зеленых водорослей, в котором криптомонады и диатомовые потреблялись более интенсивно, чем зеленые. В исследовании (Antajan, Gasparini, 2004) аллоксантин всегда обнаруживался в экстрактах веслоногих рачков, обитающих в морской воде, но не было обнаружено корреляции с аллоксантином в воде и не наблюдалось значительного потребления Cryptophyceae. Из этого был сделан вывод, что аллоксантин может накапливаться рачками в тканях организма в течение долгого времени и его наличие не подходит для количественной или качественной оценки потребления криптофитовых в текущий момент.

Накопление аллоксантина (и вообще каротиноидных пигментов) у копепод часто описывается как пластическая адаптация, обеспечивающая фотозащиту от ультрафиолетового излучения. Некоторые исследования ставят эту гипотезу под сомнение. Например, Schneider et al. (2016) сообщают о максимумах содержания каротиноидов зимой, когда ультрафиолетовое излучение низкое, и вводят предположение, что такое накопление связано с метаболизмом липидов и антиоксидантной функцией каротиноидов, а не с фотозащитой, и что сезонные изменения содержания каротиноидов в тканях копепод связаны с циклом воспроизводства (Schneider et al., 2017).

Существуют данные и о том, что метод пигментного хроматографического анализа в исследовании питания копепод нужно использовать с осторожностью. Так, у (Descy et al., 1999) реальное потребление водорослей в экспериментах с кормлением Diaptomus minutus водорослевым сообществом не коррелировало с содержанием маркеров этих водорослей в кишечниках веслоногих рачков, причем именно маркер криптофитовых аллоксантин наблюдался в кишечниках постоянно. В этом исследовании также отмечается, что каротиноиды могут разрушаться, находясь в кишечниках копепод и аллоксантин наименее подвержен такому разрушению. Подобное утверждают и Pandolfini et al. (2000): пигментные профили экстрактов кишечника плохо отражали диету копепод. McLeroyEtheridge, McManus (1999) описывают значительную вариабельность разрушения различных пигментов в кишечниках копепод в зависимости как от видов водорослей, так и от способа кормления веслоногих рачков. Antajan, Gasparini (2004) утверждают, что есть возможность преобразования веслоногими рачками в аллоксантин других потребленных каротиноидов. Тем не менее напомним, что источником аллоксантина в кишечниках и тканях копепод считаются только криптофитовые водоросли.

\section{Заключение}

Исследования содержания каротиноида аллоксантина в осадочных илах, седимен- 
тационных ловушках, зоопланктоне озера Шира и анализ связей между ними показали, что существует высокая вероятность того, что криптофитовые водоросли в озере Шира селективно выедаются веслоногим рачком A. salinus.

\section{Список литературы / References}

Кузьмин Г.В. (1975) Фитопланктон. Методика изучения биогеоценозов внутренних водоемов. Мордухай-Болтовской Ф.Д. (ред.) М., Наука, с. 73-87 [Kuzmin G. V. (1975) Phytoplankton. Methods of ecosystem studies in inland waters. Mordukhai-Boltovsky F.D. (ed.) Moscow, Nauka, p. 73-87 (in Russian)]

Науменко Ю. В. (2014) Криптофитовые водоросли в водотоках и водоемах западной Сибири. Растительный мир Азиатской России, 1: 3-8 [Naumenko Yu.V. (2014) Cryptophyte algae in streams and water bodies of west Siberia. Plant Life of Asian Russia [Rastitelny mir aziatskoy Rossii], 1: 3-8 (in Russian)]

Радченко И.Г., Капков В.И., Федоров В.Д. (2010) Практическое руководство по сбору и анализу проб морского фитопланктона. М., Мордвинцев, 60 с. [Radchenko I. G., Kapkov V.I., Fedorov V.D. (2010) Manual on collection and analysis of marine phytoplankton. M., Mordvintsev, 60 p. (in Russian)]

Тевяшова О.Е. (2009) Сбор и обработка зоопланктона в рыбоводных водоемах. Методическое руководство (с определением основных пресноводных видов). Ростов-на- Дону, Изд-во АзНИИРХ, 84 c. [Tevyashova О.Е. (2009) Collection and processing of zooplankton in fish-breeding reservoirs. Methodological guide (with the identification of the main freshwater species). Rostov-onDon, Azov Research Institute of Fisheries, 84 p. (in Russian)]

Antajan E., Gasparini S. (2004) Assessment of Cryptophyceae ingestion by copepods using alloxanthin pigment: a caution. Marine Ecology Progress Series, 274: 191-198

D'Souza A.M., Gauns M.U. (2018) Temporal variability in copepod gut pigments over the central western continental shelf of India. Journal of the Marine Biological Association of the United Kingdom, 98(1): 149-159

Degermendzhy A.G., $\quad$ Zadereev E.S., $\quad$ Rogozin D.Y., $\quad$ Prokopkin I.G., $\quad$ Barkhatov Y.V., Tolomeev A.P., Khromechek E. B., Janse J.H., Mooij W. M., Gulati R.D. (2010) Vertical stratification of physical, chemical and biological components in two saline lakes Shira and Shunet (South Siberia, Russia). Aquatic Ecology, 44(3): 619-632

Descy J.P., Frost T.M., Hurley J.P. (1999) Assessment of grazing by the freshwater copepod Diaptomus minutus using carotenoid pigments: a caution. Journal of Plankton Research, 21(1): 127-145

Dunstan G.A., Brown M.R., Volkman J.K. (2005) Cryptophyceae and rhodophyceae; chemotaxonomy, phylogeny, and application. Phytochemistry, 66(21): 2557-2570

Eilertsen H.C., Taasen J.P., Weslawski J. M. (1989) Phytoplankton studies in the fjords of west spitzbergen - physical-environment and production in spring and summer. Journal of Plankton Research, 11(6): 1245-1260

Gaevsky N. A., Zotina T. A., Gorbaneva T. B. (2002) Vertical structure and photosynthetic activity of Lake Shira phytoplankton. Aquatic Ecology, 36(2): 165-178

Gervais F. (1998) Ecology of cryptophytes coexisting near a freshwater chemocline. Freshwater Biology, 39(1): 61-78

$$
-165-
$$


Gladyshev M. I., Temerova T. A., Dubovskaya O. P., Kolmakov V. I., Ivanova E. A. (1999) Selective grazing on Cryptomonas by Ceriodaphnia quadrangula fed a natural phytoplankton assemblage. Aquatic Ecology, 33(4): 347-353

Hairston N.C. (1976) Photoprotection by carotenoid pigments in the copepod Diaptomus nevadensis. Proceedings of the National Academy of Sciences of the United States of America, 73(3): 971-974

Hasle G. R. (1978) The inverted-microscope method. Phytoplankton manual. Sournia A. (ed.) Paris, UNESCO, p. 88-96

Head E.J.H., Harris L.R. (1994) Feeding selectivity by copepods grazing on natural mixtures of phytoplankton determined by HPLC analysis of pigments. Marine Ecology Progress Series, 110(1): 75-83

Klaveness D. (1988) Biology and ecology of the Cryptophyceae: status and challenges. Biological Oceanography, 6(3-4): 257-270

Knisely K., Geller W. (1986) Selective feeding of four zooplankton species on natural lake phytoplankton. Oecologia, 69(1): 86-94

Leavitt P.R. (1993) A review of factors that regulate carotenoid and chlorophyll deposition and fossil pigment abundance. Journal of Paleolimnology, 9(2): 109-127

Marshall W., Laybourn-Parry J. (2002) The balance between photosynthesis and grazing in Antarctic mixotrophic cryptophytes. Freshwater Biology, 47(11): 2060-2070

McLeroy-Etheridge S.L., McManus G.B. (1999) Food type and concentration affect chlorophyll and carotenoid destruction during copepod feeding. Limnology and Oceanography, 44(8): 2005-2011

Meyer-Harms B., Irigoien X., Head R., Harris R. (1999) Selective feeding on natural phytoplankton by Calanus finmarchicus before, during, and after the 1997 spring bloom in the Norwegian Sea. Limnology and Oceanography, 44(1): 154-165

Oechsler-Christensen B., Jonasdottir S.H., Henriksen P., Hansen P. J. (2012) Use of phytoplankton pigments in estimating food selection of three marine copepods. Journal of Plankton Research, 34(2): 161-172

Pandolfini E., Thys I., Leporcq B., Descy J.P. (2000) Grazing experiments with two freshwater zooplankters: fate of chlorophyll and carotenoid pigments. Journal of Plankton Research, 22(2): 305-319

Porter K. G. (1988) Phagotrophic phytoflagellates in microbial food webs. Hydrobiologia, 159(1): 89-97

Reynolds C.S. (1992) Dynamics, selection and composition of phytoplankton in relation to vertical structure in lakes. Ergebnisse der Limnologie, 35: 13-31

Rogozin D.Y., $\quad$ Tarnovsky M.O., $\quad$ Belolipetskii V.M., $\quad$ Zykov V.V., $\quad$ Zadereev E.S., Tolomeev A.P., Drobotov A.V., Barkhatov Y.V., Gaevsky N.A., Gorbaneva T.B., Kolmakova A.A., Degermendzhi A.G. (2017) Disturbance of meromixis in saline Lake Shira (Siberia, Russia): Possible reasons and ecosystem response. Limnologica, 66: 12-23

Rogozin D. Y., Zykov V. V., Chernetsky M. Y., Degermendzhy A. G., Gulati R. D. (2009) Effect of winter conditions on distributions of anoxic phototrophic bacteria in two meromictic lakes in Siberia. Aquatic Ecology, 43(3): 661-672

Rogozin D. Y., Zykov V.V., Kalugin I. A., Daryin A. V., Degermendzhy A. G. (2011) Carotenoids of phototrophic organisms in bottom sediments of meromictic Lake Shira (Siberia, Russia) as an indicator of past stratification. Doklady Biological Sciences, 439: 228 
Schneider T., Grosbois G., Vincent W.F., Rautio M. (2016) Carotenoid accumulation in copepods is related to lipid metabolism and reproduction rather than to UV-protection. Limnology and Oceanography, 61(4): 1201-1213

Schneider T., Grosbois G., Vincent W. F., Rautio M. (2017) Saving for the future: Pre-winter uptake of algal lipids supports copepod egg production in spring. Freshwater Biology, 62(6): 1063-1072

Sommaruga R. (2010) Preferential accumulation of carotenoids rather than of mycosporine-like amino acids in copepods from high altitude Himalayan lakes. Hydrobiologia, 648(1): 143-156

Sushchik N.N. (2008) Role of essential fatty acids in trophometabolic interactions in the freshwater ecosystems (a review). Zhurnal Obshchei Biologii, 69(4): 299-316

Talling J.F. (2003) Phytoplankton-zooplankton seasonal timing and the 'clear-water phase' in some English lakes. Freshwater Biology, 48(1): 39-52

Tonno I., Agasild H., Koiv T., Freiberg R., Noges P., Noges T. (2016) Algal diet of small-bodied crustacean zooplankton in a cyanobacteria-dominated eutrophic lake. Plos One, 11(4): e0154526

Wright S. W., Jeffrey S. W., Mantoura R.F.C., Llewellyn C.A., Bjornland T., Repeta D., Welschmeyer N. (1991) Improved HPLC method for the analysis of chlorophylls and carotenoids from marine-phytoplankton. Marine Ecology Progress Series, 77(2-3): 183-196

Zykov V. V., Rogozin D. Y., Kalugin I. A., Dar'in A.V., Degermendzhi A. G. (2012) Carotenoids in bottom sediments of lake Shira as a paleoindicator for reconstruction of Lake States in Khakassiya, Russia. Contemporary Problems of Ecology, 5(4): 434-442 